Portugalsky, P. V. (2020). Conservation and restoration of frames with stucco mastic decor. Current Issues of Cultural Heritage in 2020. European Scientific e-Journal, 1(1), 114-133. Hlučín-Bobrovníky: "Anisiia Tomanek" OSVČ.

Португальский, П. В. (2020). Консервация и реставрация рам с мепным мастичным декором. Current Issues of Cultural Heritage in 2020. European Scientific e-Journal, 1(1), 114-133. Hlučín-Bobrovníky: "Anisiia Tomanek" OSVČ.

DOI: $10.47451 /$ her2020-08-002

The paper is published in Crossref, ICI Copernic, BASE, Zenodo, OpenAIRE, LORY, HSLU, J-Gate, Academic Resource Index ResearchBib, ISI International Scientific Indexing, eLibrary, Mendeley, and WebArchive databases.

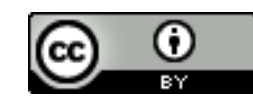

Peter V. Portugalsky, кеsearcher, restorer of works of applied art. St. Petersburg, Russia.

\title{
Conservation and restoration of frames with stucco mastic decor
}

Abstract: The relevance of the chosen topic is that picture frames are valuable cultural objects. The production of artistic baguette frames with mastic decoration, gilding, imitation gilding and other decorative coatings has a long tradition and developed production technology. The study of frames allows you to get valuable information about the artistic styles of frames, about the technology of their production, to develop acceptable methods of restoration, which many frames need. The author reveals the ways and methods of conservation and restoration of a particular frame with imitation gilding to a painting from a private collection. It describes the state of preservation of the object before restoration and determines the sequence of methods for eliminating defects in the frame to give it an expositional appearance, and then describes the processes of working on the frame. The author concludes that the frame and the painting are separate works of art and craft, but they are created for each other. The picture, of course, takes precedence, the frame plays a secondary role, but they interact and complement each other.

Keywords: conservation and restoration of objects of applied art, olive decor, frame.

Пётр В. Португаньский, реставратор произведений АПИ, исследователь. Санкт-Петербург, Россия.

\section{Консервация и реставрация рам с лепным мастичным декором}

Аннотащия: Актуальность выбранной темы заключается в том, что рамки Аля картин явАяются ценными культурными объектами. Производство художественных багетных рам с мастичным Аекором, позолотой, имитацией позолоты и Аругими Аекоративными покрытиями имеет Аавние традиции и развитую технологию производства. Изучение рам позволяет получить ценную информацию о художественных стилях рам, о технологии их изготовления, разработать приемлемые методы реставрации, в которых нужАаются многие рамы. Автор раскрывает способы и методы консервации и реставрации конкретной рамы с имитацией позолоты к картине из частной комлекции. В нем описывается состояние сохранности объекта до реставрации и определяется последовательность методов устранения дефектов в раме Аля придания ей экспозиционного виАа, а затем описываются процессы работы наА рамой. Автор делает заключение, что рама и картина - это отдельные произведения искусства и ремесла, но они 
созданы Аруг Аля друга. Картинка, конечно, имеет приоритет, рамка играет второстепенную роль, но они взаимодействуют и Аополняют Аруг Аруга.

Ключевые слова: консервация и реставрация предметов прикладного искусства, оливковый декор, рамка.

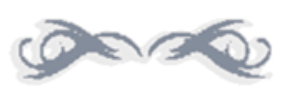

\section{Introduction}

The relevance of the chosen topic is that picture frames are valuable cultural objects. The production of artistic baguette frames with mastic decoration, gilding, imitation gilding and other decorative coatings has a long tradition and developed production technology. The study of frames allows you to get valuable information about the artistic styles of frames, about the technology of their production, to develop acceptable methods of restoration, which many frames need. Frames can have numerous traces of existence, damage and loss. Frames are works of applied art. Many of them are valuable, which increases the artistic value and value of the frames.

The theme of frames' restoration for paintings is not developed enough. There are few publications specifically on frames, mostly articles in the catalogues of relevant Museum exhibitions, in art encyclopedias and in restoration collections. Information about the history of frames, their styles, details and subtleties of technology are scattered in works on architecture, gilding, painting and carpentry. Sketchy, but very important information on this issue contains works on iconography and the art of carving. Information in books on the restoration and gilding of furniture and frames often repeats the corresponding places in the works of earlier years of publication.

\section{Purpose, objectives and methods of the project work}

The purpose of the work was to restore the frame with stucco mastic decoration and imitate gilding and development of a theoretical basis for its implementation.

Tasks, which were set during the project:

- explore the history of Rama in European and Russian art;

- research technologies for the production of baguette frames with mastic decor, technology for applying artistic finishes and their development;

- investigate and describe this frame, get information about its history, design, and condition;

- create a methodology for frame restoration and approve it from the scientific supervisor and the restoration Council;

- $\quad$ perform restoration of the frame and hand over the object to the restoration Council;

- draw up and issue appropriate documentation.

Object of research was decorative and applied arts of the $18^{\text {th }}, 19^{\text {th }}$, and $20^{\text {th }}$ centuries.

The subject of the study was a frame for painting at the turn of the $19^{\text {th }}$ and $20^{\text {th }}$ centuries of factory production with mastic decoration and imitation gilding.

The methodological basis of the research consisted in the application of historical and analytical methods. The historical and archival method was used for searching libraries and 
electronic sources of information and studying printed works and images that cover these aspects of history, chemistry, technology and methods of restoration and crafts. The comparative method was used to find analogs of decoration, construction and production techniques in other frames for painting. The technical and technological method included studies of the restoration object itself (the frame), which are carried out by non-damaging methods: inspection, measurement, organoleptic analysis, taking scraps and samples from low-visibility places, mechanical and chemical tests with these samples. Consultations of specialists in these areas were used, as well as personal previously acquired knowledge in these areas and personal experience in conducting research and restoration work.

\section{Description of the restoration object}

The frame received for restoration, judging by the style and materials of finishing in the form of three types of imitation gilding, can be attributed to the last quarter of the $19^{\text {th }}$ or early $20^{\text {th }}$ century. During this period of time, various and highly developed technologies of production and decoration were used in the frame business. The artists created a lot of sketches of baguettes, overlays and frames in General for every taste and style. Industry and master baguettes could offer a wide range of baguettes and frames of various levels, from elite, made with all the subtleties of the craft, to mass-produced from factory blanks, but at the same time an acceptable level and quality.

The object of The Frame for a Picture Made of Baguette on a Wooden Base with Mastic Decoration and Imitation of Gilding (Figure 1; Figure 3) was accepted for restoration work.

There is very little information about the object, and there are no brands, signatures, numbers, or other marks on the frame. The frame was purchased already in a damaged condition, cheap, and the new owners did not use it for its intended purpose. In their private collection of paintings and drawings, there were no works of this format, there were doubts about the style, and so the hands did not reach the restoration or alteration. The frame was stored in acceptable conditions along with other frames from the late 1970s of the twentieth century until October 2018, when it was transferred for restoration with the desire to restore its exposition and operational properties without changing the size, without updating, that is, with the preservation of "traces of time".

The examination of the frame itself allowed us to state the following fairly confidently and objectively, with physical evidence:

Frame dimensions: external $70.5(71) \times 61.7(62.2) \mathrm{cm}$; internal $38 \times 29.5 \mathrm{~cm}$; socket for painting 41 (42.2) x $32.5 \mathrm{~cm}$; fold depth $1.5 \mathrm{~cm}$.

The frame format was "official". The frame was made of a baguette $16 \mathrm{~cm}$ wide and $9 \mathrm{~cm}$ thick, a complex profile, that is, its prototype was the baguette frames earlier than the beginning of the 20th century. Art Nouveau baguettes look different, but Soviet frames of this size are usually narrower and much thinner, for purely domestic reasons.

The frame style was eclectic. The decor was classical or empire style garlands with ribbons, and "beads" was connected with the large angular Racisme and roller with twisted floral ornament. The frame was very elegant, 'playing' with different textures and chiaroscuro, but it did not pretend to a high artistic style and level of performance. 
The basis of the baguette made of pine wood is made competently and efficiently. The profile of the mouldings was made up of several (at least four) pine slats, sawn and planed clearly on mechanical machines from a well-selected and seasoned material.

The slats were the same and smooth, there were no defects (cracks, tarring, rot) on the visible surfaces. There were healthy knots with smooth sections -3 pieces, and one bully on the oblique layer. Adjustment and fine-tuning during assembly were carried out with hand tools because of traces of tinabula and scrappers. There were shrinkage and warping of the usual values for products of this type and age. Connections with joiner's glue were made cleanly. The exit of excess glue at the joint was only available in one place $10 \mathrm{~cm}$ long. The adhesive joints were made without fixing with a metal fastener. The longitudinal glues were still holding up well, but they had separated, but not collapsed, only at the base of the joint.

The design of the wooden frame base was also well thought out. The slats on the back of the baguette formed a voluminous longitudinal groove with a width of $3.8 \mathrm{~cm}$ and a depth of $2.2 \mathrm{~cm}$, which facilitates the overall weight and reduces warping. The plastic joints were sawn and adjusted precisely, clearly in a special sawing machine, using a fine-toothed saw with a tensioned blade. A hacksaw in a mitre box that result when regular work was difficult to obtain.

The frame assembled from a baguette was fitted with an additional frame-binding-made of pine slats $2.5 \mathrm{~cm}$ wide and $1.5 \mathrm{~cm}$ thick. The internal four slats formed a fold of the window for painting with a width of $32.5 \mathrm{~cm}$, height of $41 \mathrm{~cm}$ and depth of $1.5 \mathrm{~cm}$ according to the size of the subframe or the basis of the customer's painting. This binding had H-form with two crossbars; four protrusions on the upper and lower panels overlap the inner groove.

Four similar slats with a beveled outer edge formed the outer binding and went exactly along the perimeter of the frame, increasing its thickness by the depth of the fold. All slats of the internal binding were glued to the base of the baguette and fixed with small nails with round caps at irregular intervals of $9-13 \mathrm{~cm}$. The nails were obviously factory-made.

The rails of the internal binding had a rectangular inset, the corners of the external ones were filed with a mustache. The use of small nails fixing the adhesive connection was quite justified, because it was not necessary to press the products with such a complex and fragile artistic surface with clamps, bends or vayma.

The vertical faces of the internal binding rails on the upper and lower panels had a small blockage inside. In the middle of the vertical sheets in the rails of the base of the baguette next to the rails of the inner binding, there was a pair of holes with a diameter of $4 \mathrm{~mm}$ with a screw thread inside. These were undoubtedly the places where the lost screw anchors were installed with rings for tying the cord on which the frame was hung. The location of the fasteners indicates that the frame was originally used vertically. There were no tool marks near the holes and no traces of the anchors being torn out - they were carefully twisted out.

On the lower leaflet on the inner side, five holes with a diameter of 0.8-1 mm were found, clearly of organic origin, that is, the exit places of tree-eating beetles.

The decorative surface of the frame was not made individually, but by a manufacturing method. On the primed surface of the base of the baguette, a relief of mastic, gypsum, and sand was applied, and on them - a decorative coating above.

The simplest test for the composition of mastic was performed by scratching and sawing with a file of the fallen fragment, with igniting and diluting parts of the resulting powder in water. 
By the nature of sawing and the smell of burned material, it could be argued that in its composition, mastic had, in addition to chalk, a large content of gypsum, a lower content of bone meal, and as a binder - water-soluble glue.

Mastics of this recipe are cheap, strong and durable (there was no transverse cracking characteristic of 'oil' mastics), but they do not allow you to form a deep relief with small and clear details.

On this terrain, all the elements were low (including small galteli), and all look 'licked', 'smudged'. Mastic had been applied to the ground of the base by rolling a special relief shaft, solid or set. In this case, there were two such knurlings - on the outer and inner sides of the baguette. This method allowed you to get a baguette of any length, more precisely, the length of the prepared base.

On the top plate of the baguette, the main cut was set in the form of a garland, intertwined with a ribbon. The cut from plaster with glue without reinforcement was made separately from the baguette by casting in an open form. After drying and fitting its base to the plane of the plate, the cut was glued with water-soluble glue to the mastic surface of the baguette. After that, on the surface of a large galteli, a texture powder made of quartz sand was applied to the glue layer.

After that, the decorative finishing of the baguette surface was performed. In this form, the factory baguette was sold to workshops that made frames to order. In these workshops, the baguette was cut at an angle of 45 degrees on sheets of specified sizes.

It can be assumed that the sawing was carried out in special devices (the saws were made exactly), in the direction from the outside of the baguette to the inside to avoid blunting the teeth of the saw blade on the quartz sand of the powder. Separately, corner elements were supplied - rocailles that were installed in the corners after the frame was assembled. Installation was performed in the simplest way - by adding a surcharge. On the back side of the rocaille and on the place where it was installed on the frame, a lump of thickening plaster with glue was applied, and the rocaille was put in place. The lumps flattened against each other, stuck together, and after solidifying, connected the rocaille to the frame, filling the gap formed between them.

The assembly was performed "without fuss", with a minimum volume of gypsum, so as not to remove the excess that has come out. The resulting undercurrents along the edges of the middle parts of all four rocailles were not filled in or masked in any way. The rocaille molded in an open form, without reinforcement, of the same material as the cutting.

The reverse surface was adjusted to the corner of the frame with a knife and file. The fact that the frame was not made individually, but in the size of the finished baguette and overhead elements, says inconsistency in the corners of the drawing of leaves, cuts and beads.

There were four types of artistic and decorative coatings:

- semi-gloss "gold" varnish;

- glossy "gold" varnish;

- glossy lacquer "patinated brass";

- matt rough surface of the color of oxidized copper-powder.

Lacquer coatings were applied to the tinted base color of oxidized and contaminated bronze and brass so that the base remained visible in the recesses of the relief, creating the effect of "old", i.e., worn, patinated and contaminated metal relief. It was possible that the altering, that 
is, the aging of the decorative surface was supplemented by the spraying of small drops of darker varnish in order to simulate chemical and biological contamination.

The surface bore traces of artisanal renovation: you could see tints with 'gold' varnish (bronze powder on the varnish) on the vertical and lower horizontal leaves on the outer cut with beads.

The work was done sloppy. There were visits of paint on the surface of the bead with fillets on varnish colour patinated brass. The same tints were also present on the main cut. The new varnish differed in colour and gloss from the original one, it had significantly degraded and peeled off, revealing the genuine surface of the product.

There was no information about what kind of work of fine art or other image this frame was made for, but there was a fold of the window for painting.

According to its dimensions, we could conclude that a certain plate had been inserted into the frame with a height of $40-41 \mathrm{~cm}$, a width of $31-32 \mathrm{~cm}$ and a thickness of no more than 1.5 $\mathrm{cm}$.

Only five small round holes with a diameter of $0.5-0.7 \mathrm{~mm}$, located irregularly and at different depths from the window plane, possibly from glass nails, were found of the traces of fasteners on the inner perimeter of the fold. There were no traces of regularly placed brackets, petals, pressure pads, kerchiefs, or traces of adhesive fasteners.

Loss of the main stucco decoration were one corner element in the upper-left corner is completely lost, except for fragments of the end leaves.

A fragment of the end sheet missed at the upper-right element.

The main cut had losses: on the left vertical leaflet $22.7 \mathrm{~cm}$ long, on the right vertical leaflet $6.2 \mathrm{~cm}$ long, on the lower leaflet $13.2 \mathrm{~cm}$ and $5.5 \mathrm{~cm}$.

There was chipped decor in all four corners. There were chips in the remaining three corner elements.

The protruding elements of the main cut and corner elements were scratched and worn in many places, in four places to the base.

The main cut on the right, left and upper leaves had transverse dissecting cracks with small chips.

On the right and left galtel, which limits the window for painting, there were chips of mastic in the size of 2,6x1,4 cm to the base.

On the right leaflet on a large half-roll there was a chip of mastic to the base size of $1,9 \mathrm{x} 1$, $0 \mathrm{~cm}$.

On the ledge that restricts the outer side of the frame, there were numerous small scuffs, chips and cracks of the mastic layer from 2 to $0.5 \mathrm{~cm}$.

The loss of elements of gypsum decoration was caused by cracking of gypsum and delamination of gypsum-adhesive binder as a result of fluctuations in temperature and humidity of the environment for a long time.

When the wooden base shrank, the gluing of the plastic joints separated. Because of this, the mastic flaked off in the same places.

The rest of the damage (scuffs, chips and cracks) was caused by mechanical impact during household cleaning of dirt and accidental minor impacts. The frame had clearly never fallen from a height greater than its own - there was no characteristic damage (Figure 2; Figure 3). 
The most difficult thing to guess was what had been originally inserted into this frame, for which it was ordered to be framed. The pompous look said something important to the owner. Vertical orientation primarily involves a portrait, but it could be a still life, a genre scene, or a landscape, such as a mountain or city.

It is more likely to be a representative portrait: the frame was not expensive, but it imitated a very expensive one, it was made of a standard baguette, but it fitted a certain size, and the style is probably also chosen.

The format was "cabinet". The decor, despite the rockails, did not cause any lyrical or romantic moods. Such a frame could be ordered for a portrait or portrait of a close person by a client who was not rich, but ambitious: a novice lawyer, a retired military man, etc.

It could have been an oil painting on canvas and a stretcher. A subframe for paintings of this size is usually no thinner than $2 \mathrm{~cm}$, and the depth of the fold of the frame is $1.5 \mathrm{~cm}$. However, the subframe often protrudes beyond the back plane of the frame and is attached to it by pressing an additional cord between the anchors, so that no other fasteners are required.

It could also be: watercolors, pastels, tempera or graphics on paper or cardboard, as well as engraving, photography, lithography and much more. All these images do not require a stretcher, but a sheet of pressing cardboard and, necessarily, glass.

The block of "glass-paper-cardboard" was fixed in the fold with nails, kerchiefs, petals, spring klyamerams, and all this hardware was attached to the fold, leaving traces on it. Since they are almost absent on this frame, we could assume that the block with a thickness of 5-7 $\mathrm{mm}$ had been attached either with spacer wedges, or with inserts from edge to edge of the fold. In favour of the latter option, the internal faces of the upper and lower rails of the internal binding had a slight blockage inside.

Five irregularly placed traces of nails at different depths from the plane of the window for painting could be explained by the further operation of the frame, when it was inserted into another production with glasses of different thickness or without them at all.

\section{History of the restoration object}

The life path of this frame can be represented with some assumptions as follows: at the turn of the $19^{\text {th }}$ and $20^{\text {th }}$ centuries in the capital of the Russian Empire, a poor, but willing to be "no worse than others" person who is making or finished a career, for his portrait with all the regalia (most likely, photographic), ordered a frame befitting his greatness. Due to lack of funds, the order was made in a small inexpensive workshop, where the factory baguette and overhead elements were semi-artistically made to fit the size of the frame of different styles and levels, that is, all at the client's request and purse.

Career was developing, and the portrait hung in the room of his apartment or hired (depending on career development). After the revolution, the apartment became communal, the portrait changed or retained the owner or his heirs, but the image of a class-alien element was removed from it and replaced with some other, up to a reproduction from a magazine or even a mirror.

Over time, the frame deteriorated, it was artistically tinted, but when it fell off some plaster fragments, the frame was removed and put in a wall in the corridor or in a closet. A frame of 
this size will not fit on or behind the Cabinet. Or it was removed from the wall at the beginning of the blockade, and it lost some of its decoration in a damp and unheated closet.

At the same time, a few larvae of the woodworm beetle were introduced to it. Then the frame went through the transition to urban heating, the air became drier, it dried up and it got carried away, the artisanal paintwork peeled off, and the beetles died without leaving offspring.

Based on the study of special literature, consultations with specialists and personal knowledge and experience, a method of restoration was developed. It was approved by the restoration council of the department of the St. Petersburg Institute of Arts and Restoration. The restored frame was accepted by the scientific supervisor and the restoration council.

The frame for the painting from a factory baguette with mastic decoration and imitation gilding was transferred to the restoration on December 10, 2018 (Figure 1; Figure 3). General conclusion on the state of the monument was following:

1. Divergence of the angular interfaces of the frame;

2. Local loss of Foundation;

3. Presence of traces of life activity of a tree-eating beetle;

4. Local losses of stucco decoration;

5. Severe scuffs and loss of decorative finish in the form of imitation gilding;

6. Presence of unstable and persistent surface contamination;

7. The loss of the fastener.

\section{Method of restoration of a frame with stucco mastic decor}

On December 25, 2018, the restoration council of the Department of Restoration of Decorative and Applied Arts approved the following program of restoration works:

1. Removal of unstable surface contaminants;

2. The restoration of the corner mates and the restoration of lost fundamentals;

3. Insecticidal flight holes in the wood of the back side of the frame;

4. Modeling, forming and recreating local losses of stucco decoration;

5. Removal of persistent surface contamination;

6. Recreating decorative finishes within the boundaries of loss;

7. The reconstruction of the fasteners of the frame.

In order to implement this program, the following actions were had to:

1. Remove unstable surface dirt, the frame should have been swept with bristle brushes (20 and $50 \mathrm{~mm}$ ). Work should have been carried out with great care, trying not to displace or separate loosely held decorative elements and fragments of decoration. The separated fragments should have been collected, marked and fixed in their former place on the frame.

2. Perform sweeping by placing the frame so that the removed dirt does not settle on it again.

3. Clean up more narrow bristle brush with short hair and neaten, as mentioned above in the undercut, the lowlands of the terrain and other inaccessible places contamination. It is possible to use spot blowing with a rubber enema, the use of a vacuum cleaner is possible, but very carefully, and only non-contact, to absorb the dust raised in the air.

4. When restoring the corner joints of the frame, it was necessary to remove the old glue from the joint surface. To do this, the frame should have been placed face down on a soft base, eliminating damage to the decor and finish. To remove old joiner's glue from the joint 
surfaces dry or with a weak moistening with water applied with a bristle brush. The glue should be cleaned and scraped with a scalpel and special cycles and teeth made from fragments of a hacksaw blade on metal on an abrasive wheel. Both sharpened edges and web teeth are used. Dedusting of the work place should have been performed constantly after each process and operation on the frame.

5. Prime the cleaned joints with glutinous glue $\left(5 \%, \mathrm{t}=50^{\circ} \mathrm{C}\right)$, which should be applied with a small bristle brush or, in narrow places, with a steel dental spatula. From pine wood, 5 pieces of wedge-shaped inserts must be made and precisely adjusted to the places of inserts. They should be glued on glutinous glue $\left(20 \%, \mathrm{t}=40-45^{\circ} \mathrm{C}\right)$, firmly inserting into place. If it is necessary, a specialist need to use steel spring brackets for fixing, installed through the appropriate gaskets.

6. Eliminate the 'propeller' (deviation of the frame angles from one plane), the frame should have been laid immediately after gluing the front surface up on the plane and pressed down with the necessary weight weights (it can be found out in the process of alignment), laid on the corners of the frame through soft pads made of fabric and polyurethane foam. To leave under the yoke for a day.

7. Remove the weights and retainers after the glue should have solidified and the frame should have "cured". To cut "flush" with semicircular and flat wood cutters protruding from the moustache joints of the inserts, both on the front and back of the frame. The final fit should be performed by cycling cycles from a hacksaw blade and sanding with an emery cloth "240". To clean the shavings and sawdust with a bristle brush.

8. Perform sealing the defects of the frame's rags on its reverse side by installing and pasting a wooden insert into a longitudinal groove cut out with a flat wood cutter in the place of a large rags defect.

9. Small defects should have been patched with a mixture of small pine sawdust (70\%), gypsum $(10 \%)$ and glutinous glue $\left(20 \%, \mathrm{t}=40^{\circ} \mathrm{C}, 20 \%\right.$ of the volume of the mixture). To trim and sand the seal as follows after solidification. To remove dust from the workplace using a bristle brush and a vacuum cleaner.

10. On the reverse side of the frame, where the wood did not have a varnish, paint or other coating, inserts and seals should have been tinted with a 5\% solution of aniline dye "dark pine stain" (Figure 2).

The device $A C I M A$ is used by insecticising the wood of the frame to treat the wood of the frame against the tree-eating beetle. Its $2.8 \%$ solution in $72 \%$ ethyl alcohol must be injected with a syringe into the flight holes of insect passages until full saturation. Due to the toxicity of the drug, work should be carried out using personal protective equipment and exhaust ventilation.

11. Choose clear analogs to recreate the loss of stucco decoration on the preserved decor of the frame. The surfaces of analogues within the established boundaries should have been cleared of persistent surface contamination with fabric tampons impregnated with pinene and bristle brushes with short hair. If it was necessary, the use of wooden and bone stacks is allowed for pre-sampling of contamination.

12. Analogs (angular rockail and a long fragment of the upper cut) should have been brought to the model state, finished sculptural plasticine all small defects using bone and wood 
stacks. The resulting models should have been smeared for molding - equipped with plasticine beds and sides.

13. When forming the model, it should have been necessary to lubricate with a thin layer of castor oil or medical vaseline (petroleum jelly), applied with a soft hair brush without excess and omissions.

The forming compound of Pentoelast-570 is measured by weight in a special dish and mixed with the initiator of $P-18$ in the proportion of $100 \mathrm{~g}$ by $2 \mathrm{~g}$ (approximately $2 \%$ ).

The mixture is applied with a steel spatula on the model and the bed with a layer of $2-5 \mathrm{~mm}$ thick with a tab inside the cord made of cotton gauze. On top of the layer, 4-6 "buttons" of the same, but previously frozen material is glued until the mixture solidifies. The layer is left to harden for 3-6 hours.

After the mold solidifies, a plaster casing is placed on top of it. Gypsum (the brand of GP10 ) is combined with water in the plaster, mixed with a steel spatula, and when the consistency of sour cream is reached, it is applied to the form, previously lightly greased with vaseline. As the gypsum thickens, the casing is formed as a block with a flat horizontal top. Immediately after solidification, but before the plaster gains hardness, all the faces of the block are aligned and smoothed out in cycles. One hour after the plaster solidifies, the casing is removed from the mold and the mold is removed from the model.

Care must be taken and it should avoid pinpoint application of force in order to avoid damage to the frame's decor. After disassembling the form, it and the casing must be cut remove excess and irregularities of the plaster with a knife and cut off the excess compound and gauze with scissors.

Excess clay is removed from the models using wood and bone stacks. Care must be taken not to peel off fragments of decorative coating and mastic decor with plasticine. The remaining grease must be removed from the surfaces of models by wiping them with White Spirit using fabric swabs.

Casting of new-model elements (one rockail and three fragments of cutting) is performed from a mixture of gypsum (the brand of GP-10) with water with the addition of PVA glue (5\%) and dissolved cellulose fibers $(5 \%)$. This recipe allows you to get castings with properties that are closest to the material of genuine decorative elements.

Based on a visual test (inspection of the chip and cut of the original material), samples of igniting chips of the original material and rubbing and diluting it in water, it could be concluded that the original elements had been cast from gypsum, most likely without adding chalk or kaolin, and with the introduction of a water-soluble glue (casein, dextrin, etc.) to give hardness and reduce hygroscopicity, and a very thin vegetable fiber for reinforcement, that is, to give longitudinal strength.

The mixed plaster mixture is poured into open molds, air bubbles are expelled, and the mixture is left to solidify. After it (after 1-1.5 hours), the mold should be turned over, remove the casing and carefully release the plaster cast from the flexible layer of the mold. If it is necessary, casting defects are sealed with a non-cool gypsum solution. The casting at this point should be wetted with water using a brush. All excess plaster is cut off with a knife.

Castings must be dried in room conditions for a week. 
The dried plaster molds are required to match exactly the locations of the installations with a file, knife, flat cutter on wood and needle files.

Gluing of new models on the frame, as well as disassembled original decor elements, is performed after the necessary cleaning of the back sides of the plaster parts with a knife from excess plaster primers and their fitting to the "seats". After the glue has solidified, it is necessary to putty all the cracks at the joints of new models and originals. For this purpose, an uncool gypsum solution with water with the addition of $P V A$ glue is prepared for each time according to the need. The joint surfaces are wetted with water using a bristle brush and the thickening solution is applied with a bone spatula.

When removing persistent surface contamination, two different tasks must be performed:

- remove persistent household contamination;

- remove late degraded bronze paint.

Before removing household dirt, it is necessary to make a sample on a low-temperature section of the upper leaflet of the frame. To do this, a compress of cotton wool moistened with pinene should be applied to the local area with a crust of dirt and fly prints, cover with an acrylic film to avoid evaporation and leave to react, checking every 10 minutes the degree of destruction of the contamination.

The time when the contamination can be detached from the surface without harming the surface itself should be approximately 30 minutes. Compresses are applied to places of significant persistent contamination, and after clearing are cleaned off with wooden and bone stacks. After these places and places of less significant persistent contamination are treated cleanly by wiping with pinene using cloth tampons and cotton wool micro-tampons on toothpicks.

Before removing the late colorings, you must also make a sample on the upper part of the left leaflet. Actions are performed as in the previous operation, but with the difference that the compress is impregnated with a mixture of solvent 646 and White Spirit (50\% to 50\%). Cotton wool should be applied very precisely at the place of painting. The time of slight swelling of the paint layer will be longer.

To recreate the decorative finish within the loss, it is necessary to masticate with the help of bone stacks and blades with mastic cracks and small defects in the elements of the original decor prepared in small portions according to need. Mastic composition consists of gypsum $60 \%$, chalk $10 \%$, glutinous glue $10 \%, \mathrm{t}=50^{\circ} \mathrm{C} 30 \%$ of the volume.

After solidifying the mastic, finishing treatment should be performed. Then, the new models and mastics must be impregnated with a solution of shellac (15\%) in 96\% ethyl alcohol (Fig. 4).

Restoration of defects in the texture background with powder is carried out after clearing the places of loss with a cloth swab with pinene by applying drops of glutinous glue $(20 \%, \mathrm{t}=40$ $50^{\circ} \mathrm{C}$ ) from the bone shoulder blade.

A portion of quartz sand of a suitable fraction $(0.75-0.5 \mathrm{~mm})$ is immediately poured on the glue from a paper tube. After the glue solidifies, the excess sand must be swept away with a soft hair brush and removed with a vacuum cleaner (non-contact).

It is necessary to make a mixture of the desired colors and shades from artistic watercolors of Nevskaya Palitra. These mixtures are used to paint new models, mastications, and areas of the 
textural background with squirrel brushes. After drying, all the paint must be covered with 15\% shellac twice.

Restoration of losses of imitations of metal coating and opaque and glossy gilding is performed by applying to the places of losses with soft bristle artistic brushes of artistic waxes on a wax basis (Gilding Wax, decorative wax of Highlighter) four matching colors.

To create a "gloss" on the corresponding sections of the artistic coating, it is necessary to apply car nitroemal of Technocolor-Auto on the basis of NC-217. Nitroemal is pre-released from an aerosol can into a separate container and applied to the frame with an artistic bristle brush.

After applying the "gloss", it is necessary to apply a darker colour to the interior of the decor. After drying, all areas of recreated imitations of gilding, metal, and powder must be covered with 15\% shellac (Figure 5).

To recreate the frame fastener, it is necessary to make two anchor blanks from two 100 millimeter sections of steel-3 wire with a diameter of $4 \mathrm{~mm}$. To do this, the wire must be heated with a gas burner to a temperature of about $500^{\circ} \mathrm{C}$ and bend it into a ring with an external diameter of $15 \mathrm{~mm}$ with a straight "tail" of $17 \mathrm{~mm}$ in length in a vice on a cylindrical mandrel with a diameter of $6 \mathrm{~mm}$. The excess must be cut off with a hacksaw, and the ends should be grinded needle files. Each billet should be clamped in a vise ring "tail" up and cut on it with a klupp "screw" thread $15 \mathrm{~mm}$ long. The end of the thread at the end of the "tail" to sharpen by a round needle files.

Aging (altering) of steel parts must be performed by heating the anchors with a gas burner to a temperature from 400 to $450^{\circ} \mathrm{C}$ and sharply cooling them in an aqueous soap-and-salt solution to form dark-coloured iron salts and oxides on the surface.

Anchors must be screwed into the old mounting holes. For the density of screwing into the holes, thin (up to $1 \mathrm{~mm}$ ) chips of pine wood should be pre-attached. Anchor rings must be oriented vertically (Figure 2).

\section{Conclusion}

The frame and the painting are separate works of art and craft, but they are created for each other. The picture, of course, takes precedence, the frame plays a secondary role, but they interact and complement each other.

Frames are valuable objects of cultural heritage. Many of them are works of high art and skill, they bear the features and signs of the artistic style of their time. A careful examination of the frames allows not only to understand the subtlety of this style, but also to learn the secrets and peculiarities of personal manner of the author of the project and contractor's work, the connection of the frame with the work and the interior, where they were exhibited.

Frames often carry additional valuable information. On the front side, these are plates, cards, inventory numbers, and on the back - brands, signatures, signs, Assembly marks and numbers, traces of fasteners and tools. Also, on the frames there are traces of their existence, damage, contamination, traces of alterations and restorations. These additional facts can also be useful when choosing a restoration strategy for this frame.

The frame, as a designation of the natural border of the work, appeared in ancient times. Marking the border, its material embodiment is psychologically very important for a person. Interacting with the outside world, man from the very beginning of his existence sought to divide 
this world into different zones, where each of them has its own laws, forces, and you can get your own benefits and suffer different damages. Knowledge of these laws, their limits and dictated rules of behavior was one of the main conditions for survival.

However, man, thanks to his developed brain, lives not only in the real, material world. In his head, a second reality is created that reflects and refracts the first, allowing him to study and understand the world around him, even if incorrectly, to fight with it, make peace with it, and even get away from it. This is the area where art lives.

Man has always known that it is dangerous to cross borders. Beyond the visible or invisible line, everything can be completely different. Habitual actions can cause other consequences. A person 'there' can be affected by something incomprehensible and threatening, and it can invade this familiar world through a broken border. Borders have always tended to be marked and crossed only with special rituals.

A person believed that a sign, symbol, or image was equivalent to a designated, symbolized, or depicted object or phenomenon, and they could influence each other. And that this influence was not, or it was correct and timely, amulets were hidden under clothes or in bags, and signs or images were framed, which at the right time could be "opened" or erased. The doors and Windows of dwellings also separated different areas of habitation, and they had to be connected and separated at different times. An image that conveyed something other than what was around it was also worth drawing a border 'just in case'.

At the same time, any work of art is a material object, it interacts with the real world and it often needs to be protected from it materially. Works of art enclosed in various frames were always better preserved, and people always knew this.

When in Western Europe painting separated from the walls of temples and their altars, acquired a secular character, then, quite naturally, paintings and boards continued their further path along with the frames.

Frames protected the paintings, covered their unsightly edges, but most importantly presented them to the viewer, introduced the paintings to the interiors of premises, demonstrated the status of the owner.

Frames as works of decorative and applied arts were subject to change of all artistic styles, all trends of fashion. Sometimes in a pair of picture and frames, they even occupied a dominant position, being part of the rich palace decoration, and they inserted something suitable to their style. However, over time, through the efforts of artists, the frame became an integral part of the picture, helping the viewer to perceive the canvas more deeply and fully, without being distracted by the surrounding.

The production technology of the baguette and the frames themselves has been constantly developing and improving, giving master framers the opportunity to solve a variety of tasks and achieve remarkable results in their business.

With the development of society, the need for frames appeared in an increasing number of people. Mass production of baguette and affordable frames became necessary. The industrial era of the second half of the $19^{\text {th }}$ century allowed us to solve this problem by producing mass production of a fairly high quality and artistic level. A sample of such a frame was the object of this research and restoration work. 
According to the results of research, it can be argued that this frame was made at the turn of the $19^{\text {th }}$ and $20^{\text {th }}$ centuries from a factory-made baguette and separately cast from gypsum corner linings-rocailles. The baguette was cut into sheets and assembled into a frame according to the size of the customer in a small semi-industrial workshop: the manner and quality of production of the baguette and frame vary greatly. The frame is inexpensive, but solid. It survived all the vicissitudes that fell to the share of household items of medium-level objects of decorative and applied arts in the $20^{\text {th }}$ century in St. Petersburg, but came out of them without much loss.

\section{References:}

Alcuf, D. (2016). Restoration of Old Furniture. St. Petersburg: Symposium. (In Russian)

Antsov, V. L. (1916). Gilding and Silvering on Wood and Metal: Practical Guide for Amateurs and Practitioners to Gilding and Silvering V arious Wooden and Metal Things with Gold and Silver Leaf, as well as V arious Lacquers. Petrograd, Moscow. (In Russian)

Bakhtiarov, A. A. (1915). Baguette and Frame Production. Petrograd, Moscow: A.F. Sukhova Publishing House. (In Russian)

Cennini, C. (2008). A book about Art, or a Treatise on Painting: Practical Guide. St. Petersburg: Bibliopolis. (In Russian)

Charles V. (2014). Decorative and Applied Art. St. Petersburg: Azbuka. (In Russian)

Cherepakhina, A. N. (1993). History of artistic processing of wood products. Moscow: Higher School. (In Russian)

Grimm C. (1979). Alte Bilderrabmen: Epochen, Typen, Material. München: Callwey. (In Russian)

Gurvich, A. O. (1957). Joinery Works. Moscow: Tradeservices. (In Russian)

Dedyukhina, V. S., \& Lelekova, O. V. (1976). Problems of Restoration of Carved Gilded Decor in Interiors. Moscow: Information Center for Culture and Art. (In Russian)

Gilding and Silvering of Wooden Products: Production of Baguettes, Cornices, Picture Frames, etc. (1896). Moscow: Printing House of K.A. Kaznacheyev. (In Russian)

Dress the Picture: Art Frames in Russia from the $18^{\text {th }}$ to early $20^{\text {th }}$ century: [Exhibition Catalog]. (2005). St. Petersburg: Palace Editions. (In Russian)

Kuksov, V. A., Kuksov Y. V. (1972). Material Science for Carpenters. Moscow: Higher School. (In Russian)

Kuzmichev, E., Shkulev, F. (1917). Gilding and Silvering on Wood and Metal: Practical Guide to Gilding and Silvering on Wood and Metal with Sheet Gold and Silver Leaf, Bronzing, Patinating and Bluing of Various Metal Objects. Moscow: Publishing House of the P.K. Komisarenko Bookstore. (In Russian)

Lysenko, O. A. (2017). Without Frames ... do not send exhibitions. Vasily Vereshchagin. To the $175^{\text {th }}$ Anniversary of his Birth. St Petersburg: Palace Editions. (In Russian)

Moiseichev, V. M. (1957). The Work of a Master Gilder. Leningrad, Moscow: Gosstroyizdat. (In Russian)

Nikolaev, A. S. (1949). Works of the Gilder. Moscow, Leningrad: State Architectural Publishing House. (In Russian) 
Painting and Frame. Dialogues: [to the Exhibition of Precious Frame. Picture and Frame. Dialogues, Moscow, September 10 - November 30, 2014]. (2014). Moscow: State Tretyakov Gallery. (In Russian)

Paul, M., \& Lynn, R. (1996). A bistory of European picture frames. London: Mitchell in assoc. with Merrell Holberton. (In Russian)

Schmidt, L. P. (1903). Gilding, Silvering and Bronzing on Wood: Complete Home Factory Production of Baguette for Cornices, Picture Frames... and so on .... Guide for Carpenters, Framers, Furniture Makers, Professional Masters and Amateurs: In 4 Vols. Moscow: N.N. Bulgakov Publishing House. (In Russian)

Sobolev, N. N. (1939). Styles of Furniture: [historical review]. Moscow: Publishing House of the allUnion Academy of Architecture. (In Russian)

Tarasov, O. Y. (2007). Frame and Image: Rhetoric of Framing in Russian Art. Moscow: ProgressTradition. (In Russian)

Turchin, V. S. (1971). Picture-space-frame. From the history of picture frames. Decorative Art of the USSR, 8. (In Russian)

Vlasov, V. G. (1993). Illustrated Art Dictionary. St Petersburg: JSC 'Icar'. (In Russian)

\section{Appendix}

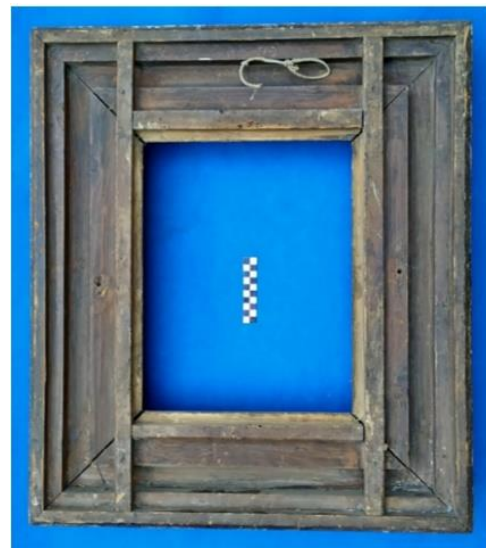

Figure 1. General view of the back of the frame before restoration

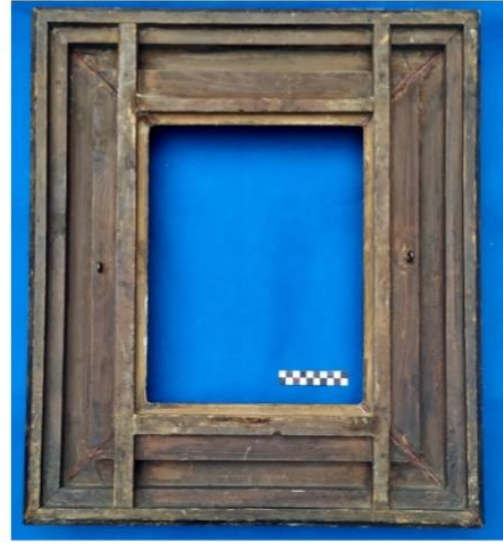

Figure 2. General view of the back of the frame after restoration 


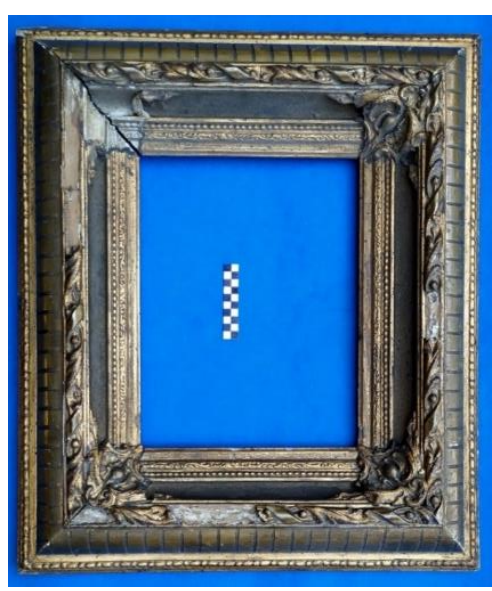

Figure 3. General view of the front side of the frame before restoration

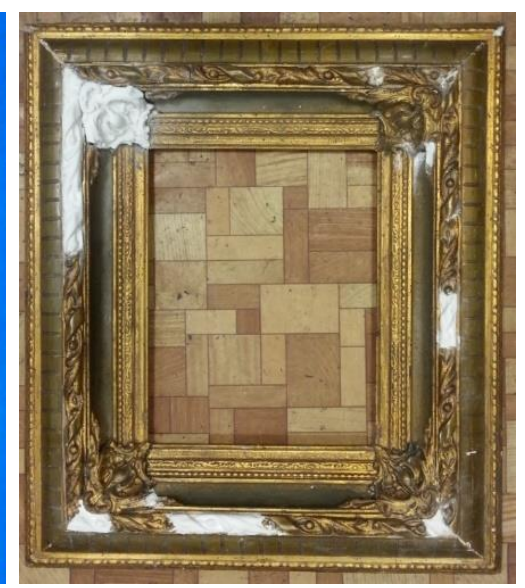

Figure 4. General view of the frame during restoration: reconstruction of local losses of stucco decoration

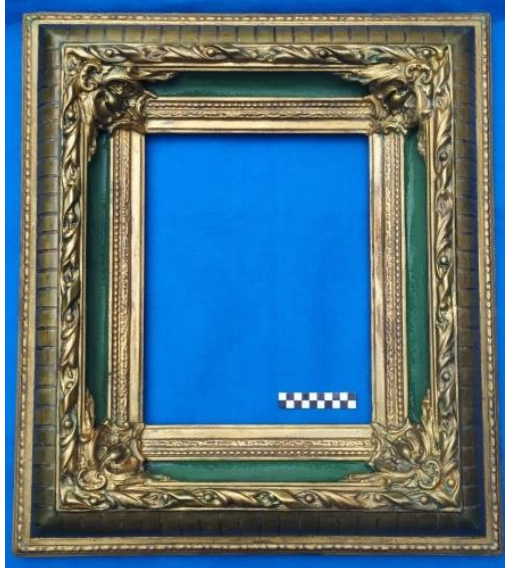

Figure 5. General view of the front side of the frame after restoration 